\title{
Konaklama İşletmelerinde Çalışan Yöneticilerin Bakım Yönetimi Uygulamalarına Bakışı: Denizli'de Faaliyet Gösteren Konaklama İşletmeleri Örneği
}

\author{
Hande Mutlu Öztürk¹, Cemal Meran"2
}

\section{ÖZ}

Bir sistemin fonksiyonlarını istenen bir düzeyde yerine getirebilmesi için gerçekleştirilen onarım, yenileme, muayene vb. faaliyetler bakım olarak tanımlanmaktadır. Sistemden kastedilen bir fabrika da ki en basitinden en karmaşığına herhangi bir makine veya ekipman olabileceği gibi, bir hastanenin elektrik, su, oksijen, 1sıtma-havalandırma vb. sistemi ya da bir otelde ki 1sıtma-soğutma, elektrik, su, kapı kilitleme sistemi, havuz vs. olabilir. Otellerde uygulanan bakım faaliyetleri, müşteri memnuniyetinin sağlanması, güvenlik ve işletme giderlerinin azaltılması açısından oldukça önemlidir. Bakım faaliyetlerinin bir yönetim anlayıșı içerisinde yönetilmesi oldukça önemlidir. Yapılan bu çalıșmayla otel işletmelerinde çalışan ve bakımdan sorumlu olan birim yöneticilerinin bakıma ilişkin bakışlarını belirlemek, kestirimci, periyodik, arızi gibi bakım yöntemlerinden hangisinin daha yaygın olduğunu belirlemek, bakım yönetimi uygulamalarını araştırmak ve otel işletmelerdeki bu faaliyetlerin uygulanmasındaki engelleri belirlemektir. Araştırmanın evrenini, Denizli'de bulunan 3, 4, 5 yıldızlı oteller ile butik konaklama işletmelerinde bulunan yöneticiler olușturmaktadır. Yapılan çalıșmada, katılımcıların en çok önem verdikleri konunun bakım ve izleme faaliyetleri olduğu gözlemlenmiştir. Bakım faaliyetlerinin yürütülmesindeki en büyük engelin de verimsiz envanter sistemi ve karşılaşılan malzeme ve yedek parça sıkıntısı olduğu görülmüştür.

Anahtar Kelimeler: Bakım, periyodik bakım, kestirimci bakım, arızi bakım, yönetici, konaklama işletmeleri

\section{The View of Managers Working in Hospitality Businesses on the Maintenance Management Practices: The Case Study for Hospitality Companies Operating in Denizli}

\begin{abstract}
The maintenance are defined as all activities which repair, renovation, inspection, etc. so that a system can perform its functions at desired level. The means of system that may be any machine or equipment from the simplest to the most complex in a factory, as well as a hospital's electricity, water, oxygen, heatingventilation etc. system or heating-cooling in a hotel, electricity, water, door locking system, pool etc. The maintenance applications in the hotels are very important in terms of ensuring customer satisfaction, reducing security and operating expenses. It is very important to manage maintenance applications with a management understanding. The purpose of this research is to determine the maintenance views of the unit managers who work in the hotel businesses and who are responsible for maintenance, determining which of the more common maintenance methods of care such as predictive, periodical, break down, to investigate the maintenance management practices and to determine the obstacles in the implementation of these applications in the hotel managment. The universe of the research is composed of managers with 3, 4, 5 star hotels and boutique accommodation businesses in Denizli. In the study, it was observed that the subject that the participants attach great importance to was maintenance and monitoring activities. The biggest obstacle in maintenance management was found to be the inefficient inventory system and the problem of materials and spare parts encountered.
\end{abstract}

Keywords: Maintenance, predictive maintenance, periodical maintenance, break down maintenance, manager, accommodation businesses.

\footnotetext{
"İletişim Yazarı

Geliş/Received

01.07.2020

Kabul/Accepted

17.07.2020

1 Pamukkale Üniversitesi Turizm Fakültesi Gastronomi ve Mutfak Sanatları Bölümü, Denizli, hmozturk@pau.edu.tr ORCID: http://orcid.org/0000-0002-4404-0106

2 Pamukkale Üniversitesi Mühendislik Fakültesi Makine Mühendisliği Bölümü, Denizli, cmeran@pau.edu.tr ORCID: http://orcid.org/ 0000-0002-1813-7166
} 


\section{GİİŞ}

Oteller hem işletilmeleri sırasında hem de bakım uygulamalarında çok farklı mühendislik uygulamalarının yapıldığı karmaşık ve maliyetli yapılardır [1]. Otel işletmelerinin bütün y1l boyunca 7 gün 24 saat boyunca hizmet veren birimler olması nedeniyle düzenli olarak korunmaları gerekmektedir [2]. Bu nedenle otel işletmelerinde bütün diğer süreçler gibi bakım sürecinin de bir planlama çerçevesi içerisinde yürütülmesi gerekmektedir. Otellerin yönetim süreçlerinde, bakım biriminin organizasyonu ve planlanması oldukça önemlidir. Bakım yönetimi, bakım işlevinin amaçlarını, stratejilerini ve önceliklerini; planlama, denetim ve kontrol gibi sorumlulukları belirleyen yönetim faaliyetleri olarak tanımlanabilir [3,4]. Otel işletmelerinde müşteri memnuniyetinin sağlanması oldukça önemlidir. Yapılan araştırmalarda, müşteri şikayetleri içerisinde bakımsızlık kaynaklı konuların (örneğin bir asansörün gürültülü çalışması veya kapı kilidinin bozuk olması gibi) en çok şikayet edilen konular arasıda 4. sırada yer aldığı görülmüştür [5]. Yapılan incelemelerde, bakım uygulamalarında bir aksama olmasa bile, otellerin yoğun olduğu dönemlerde bu şikâyetlerin arttı̆̆ görülmektedir [6]. Müşterilerin bakım ile ilgili olarak memnuniyetsizlikleri veya bakımsızlığa ilişkin olumsuz algıları, otel tipine ve ortalama günlük ücrete göre değişmektedir. Lüks otel müşterilerinin veya otellere daha yüksek ücret ödeyenlerin, ekonomik otel müşterilerinden daha fazla memnuniyetsizlik gösterdikleri ve daha fazla şikayette bulundukları gözlemlenmiştir [6,7]. Arenas ve Colina [8] yaptıkları çalışmada, otel yöneticilerinin bakım yönetimi uygulaması hakkında bilgi sahibi olmadıkları üzerinde durmuşlardır. Çoğunlukla otel yöneticileri, tesisin bakımıyla ilgili maliyetlere ya da işletme operasyonu üzerindeki etkisini fazla önemsememektedirler. Bu durum da, planlı ve önleyici bakıma yatırım yapmak yerine düzenli onarımlara (arıza bakımı) gidilmesine neden olmaktadır. Bakım yönetimi stratejilerinin genel iş performansı üzerinde etkisinin anlaşılması ve müşteri memnuniyeti üzerinde etkisinin ortaya konulması, otel yöneticilerinin bakım yönetimi uygulamalarını geliştirmesi ve bakım hizmetlerine yeterli bütçeleri tahsis etme konusunda yardımcı olabilir [9]. Bakım yönetimi, bakım optimizasyon modelleri, bakım teknikleri, bakım planlaması, bakım performans ölçümü, bakım bilgi sistemleri; ve bakım politikaları gibi farklı katagoriler altında incelenebilir. Otel işletmelerinde bakım konusu incelendiğinde, bunlardan ikisinin, otel bakımı ile ilgili araştırma belgelerinde tartışma konusu olduğu görülmektedir, bunlar: bakım teknikleri ve bakım performansı konularıdır [10].

\subsection{Otellerde Bakım Organizasyonu}

Otel organizasyonu oldukça karmaşık ve çok farklı alanların birlikte çalıştıkları yapılardır (Şekil 1). Bu yapı içerisinde bakım faaliyetleri genellikle oda servisi bölümü altında bir mühendislik hizmeti olduğundan bu birimde mühendis, tekniker veya teknisyenler görev almaktadır. 


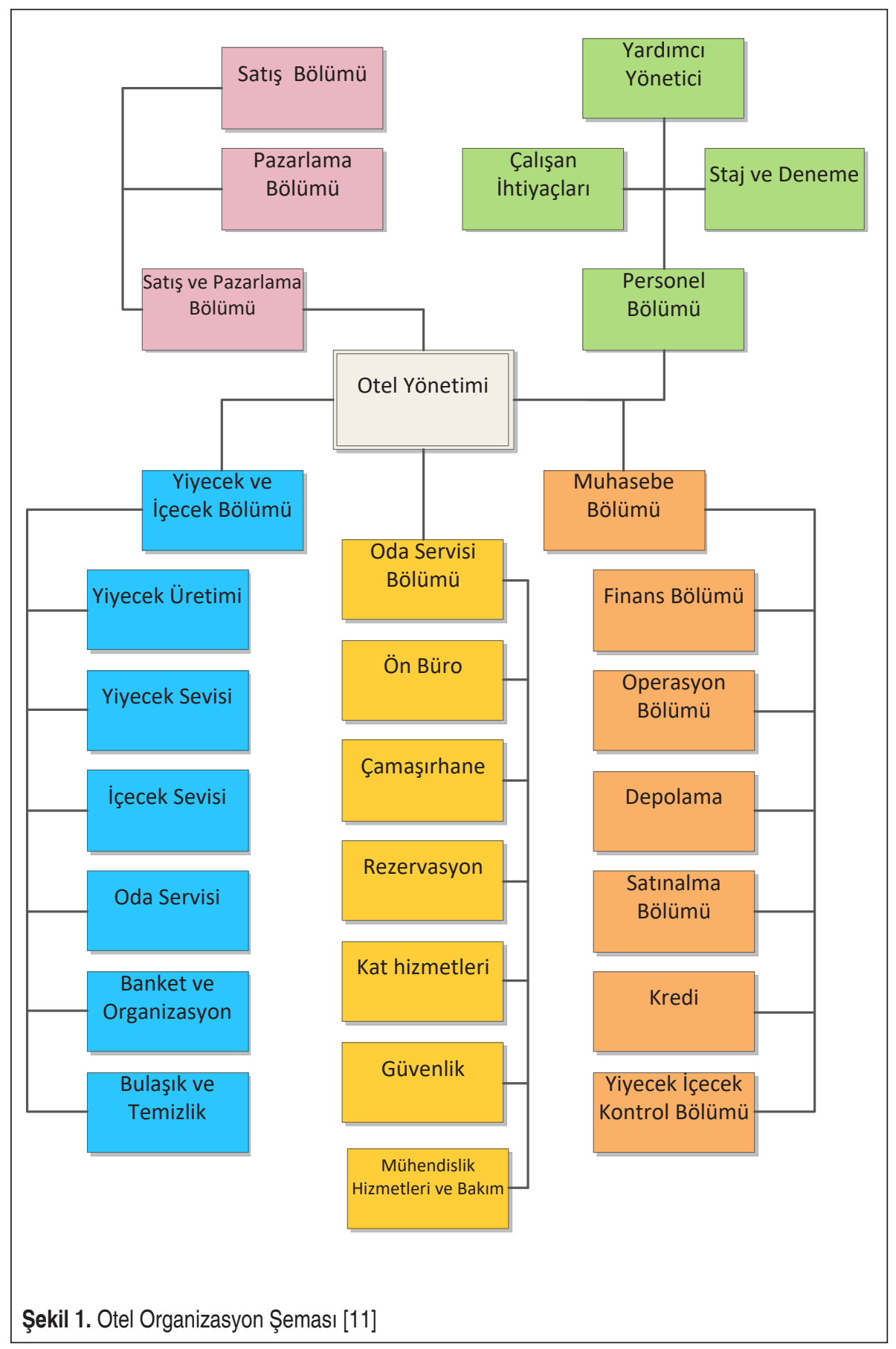


Otellerde de ekipmanların ömrünü uzatmak için bakım yapılması oldukça önemlidir. Bir ekipmanın arızalanmasından sonraki yürütülen bakıma reaktif veya plansız bakım ya da arızi bakım, arızalanmadan yapılan bakım işlemleri ise proaktif veya planlı bakım olarak adlandırılır (Şekil 2).

Arızi bakım en eski ve en yaygın bakım ve onarım stratejisi "bozulduğunda tamir et" olarak da adlandırılan reaktif veya plansız bakımdır. Arızi bakım yüksek maliyeti olmayan çok fazla yedeği bulunan tesis veya atölyelere uygulanan bakım yöntemidir. $\mathrm{Bu}$ yaklaşımın en cazip yanı hiçbir analiz veya planlamaya gerek olmamasıdır. Arıza ortaya çıkıncaya kadar bakım maliyetinin olmaması da işletmelere cazip gelmektedir. Ancak, bu bakım yönteminde, arızanın ne zaman olacağı bilinemez ve arızanın giderilmesi zaman alabilir. Problemler, bazen uygun olmayan zamanlarda ortaya çıkabilir. Bu durum da müşteri memnuniyetini olumsuz etkiler ve problemin giderilme maliyetlerinin yüksek olmasına neden olabilir. Arıza oranları, bir ekipmanın kullanım ömrü boyunca genellikle düşüktür ve ancak ömrünün sonuna doğru arızalar artar. Yeni tesislerde arızaların ortaya çıkma sıklığının az olması, otel yöneticilerini reaktif veya plansız bakıma itebilir [14]. Reaktif bakımda, bakım hizmetlerine işgücü harcanmaz veya bir arıza oluncaya kadar herhangi bir harcamaya gerek yoktur. Bakım maliyeti olmadığından, bu süre zarfında para birikmiş gibi düşünülebilir. Bakım için harcama yapmayarak sermayenin kurtarıldığına inanılmaktadır, ancak arızalar meydana geldiğinde daha büyük maliyetlerin ortaya çıkması olasılığı yüksektir. Ekipman ömrü

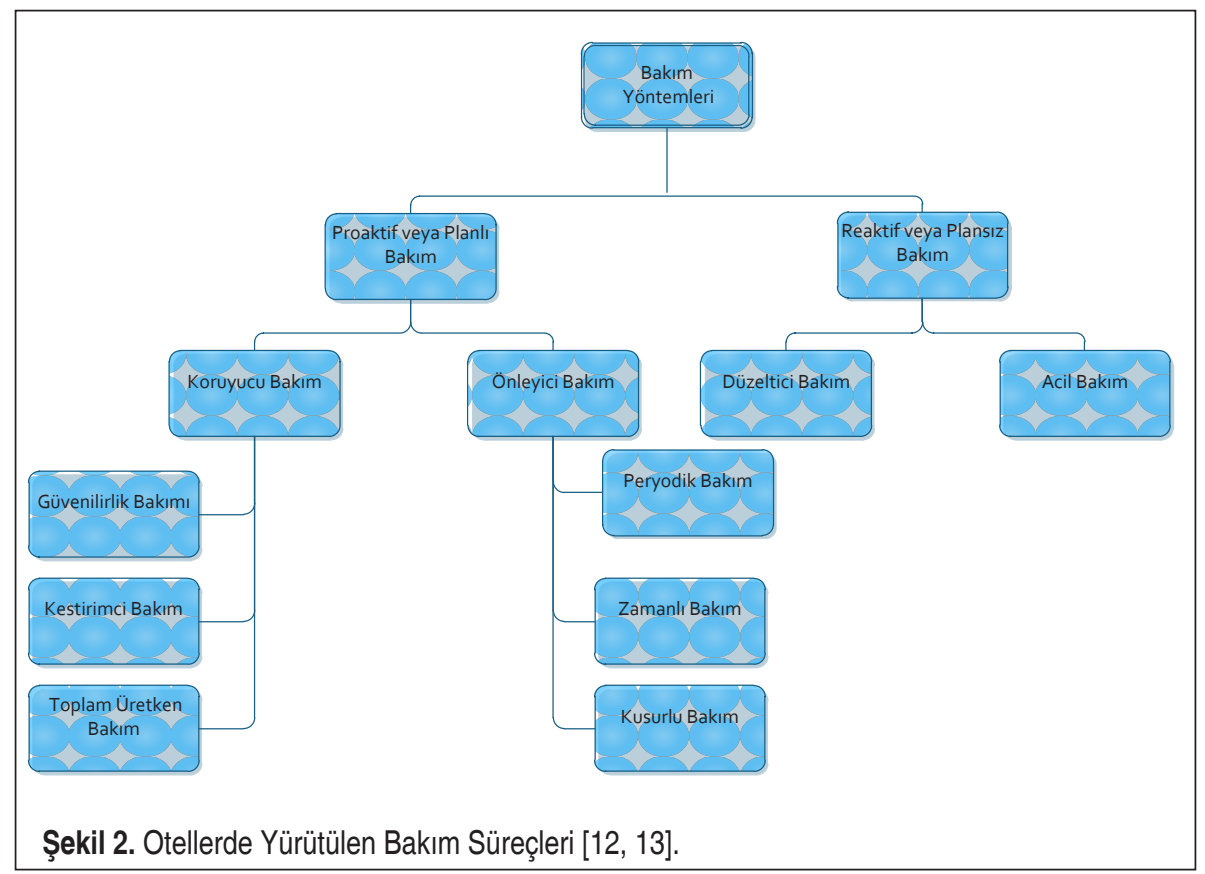


kısalabilir ve parçaların daha sık değiştirilmesi gerekebilir. Arıza meydana geldiğinde, işçilik ve parça maliyetleri normalden daha yüksek olacaktır. Reaktif veya plansız bakım, acil bakım ve düzeltici bakım olarak alt iki katagoride ele alınmaktadır. Her ikisinde de arıza meydana geldikten sonra bakım yapılmaktadır.

Planlı veya proaktif bakımda ekipmanların arıza yapması beklenmez. Koruyucu ve önleyici bakım alt kategorileri altında ele alınmaktadır [15]. Planlı bakım içerisinde yaygın olarak kullanılan bakım yöntemi periyodik bakımdır. Bu yöntemde bakım programının belirlenen bir zaman aralığında arıza olmasına bakılmaksızın periyodik uygulanması, bakım onarımda gerekli onarım, temizleme, yağlama, revizyon gibi faaliyetlerin gerçekleştirilmesidir. Otel gibi işletmelerde yaygın olarak periyodik bakım tercih edilirken beklenmedik arızlara karşı da arızi bakım yapılmaktadır. Arızi bakım gerçekte bir bakım yöntemi olmayıp tamirdir.

Her ne kadar yaygın uygulanmasa da diğer bir planlı bakım yöntemi kestirimci bakımdır. Bu bakım sisteminin ana prensibi ekipmanların performansını incelenerek ve çeşitli ölçüm cihazları kullanılarak elde edilen bilgiler ne zaman bakım gerek olacağına karar verilmesidir.

Oteller genellikle Makine Mühendisleri Odası gibi kurumların yetkin personellerine ekipmanlarının periyodik bakımlarını yaptırmaktadırlar. Genel olarak otellerin hizmet aldığı bazı periyodik bakım faaliyetleri hidrofor genleşme tankı, basınçlı kaplar, transpalet, buhar kazanı, kompresör hava tankı, sıcak su kazanı periyodik kontrolleri olarak siralanabilir.

Bakım planlama, program, uygulama ve analiz süreçlerini içerir (Şekil 3). Planlı veya proaktif bakım ile ekipmanların çalışma ömrü uzar. Ekipmanın hizmet ömrünün uzatılması para tasarrufu sağlar. Ekipman daha uzun süre kullanılabilir ve sık sık yedek parça satın alınmasına gerek duyulmaz. Planlı bakım yaparak ucuz bir maliyetle de-

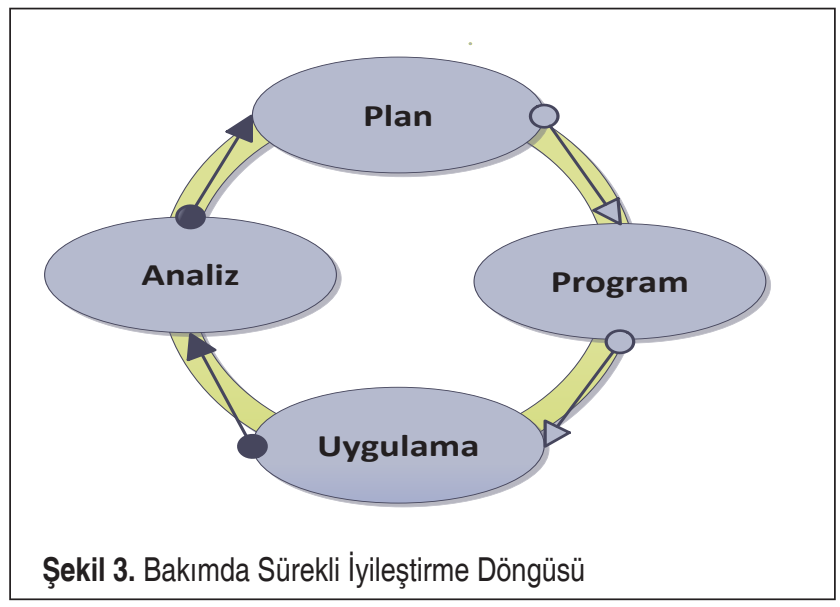


ğiştirilecek bir parçanın maliyeti çok küçük olabilir. Ancak değiştirilmemesi durumunda meydana gelebilecek bir arıza sonrasında çok daha yüksek maliyetli başka parçaların da arızalanmasına yol açabilir. Bu durum hem tamir maliyetlerini yükseltir hem de arıza süresince çalışmayan cihazlar nedeni ile şikâyetlerle karşı karşıya kalınabilinir. Örneğin, zamanında bakım yapılması nedeni ile görülmeyen veya tamirat1 yapılmayan bir yağ sızıntısı, bütün otelin klima sisteminin arızalanmasına neden olabilir. Bu durum otelin tümünde veya bu klimanın beslediği odalarda müşterilerin konaklatılamamasına ve dolayısıyla gelir kaybına neden olabilir. Bunun maliyeti değiştirilecek parça maliyetinde kat kat fazla olabilir.

Planlı bakımın en büyük avantajlarından birisi de işletme maliyetlerini azaltmasıdır. Düşük maliyetlerle değiştirilebilecek bir parça veya örneğin bakım sırasında temizlenecek bir filtre enerji maliyetlerini azaltabilir. Filtre kirlendiğinde klima öngörülen verim ile çalışamaz. Örneğin, 35 TL'lik bir filtrenin değiştirilmesi ve tıkalı bir evaporatör bobininin temizlenmesi, tüketilen elektrik miktarını $\% 50$ veya daha fazla azaltabilir. Düzenli filtre değişikliklerinin genel klima işletim maliyetlerini \% 8 ila 10 oranında azaltması beklenebilir. Büyük tesisler için bu, her sezon önemli enerji tasarrufu anlamına gelebilir [16]. Enerji giderlerinin otel işletmelerindeki değerleri göz önünde bulundurulduğunda bunun çok öenmli olduğu görülebilir [17].

Kuruluşlar aşağıdaki hedeflerden birini veya birkaçını arar: kar maksimizasyonu, hizmet veya ürünlerin belirli kalite seviyesi, maliyetleri en aza indirme, güvenli ve temiz çevre veya insan kaynakları geliştirme. Tüm bu hedefler bakımdan büyük ölçüde etkilendiğinden, bakım hedeflerinin kuruluşun hedefleri ile uyumlu olması gerektiği açıktır. Bakımın temel amacı, bir kuruluşun hedeflerine ulaşmasını sağlayacak bir hizmet sunmaktır. Bakım sistemi basit bir giriş/çıkış sistemi olarak görülebilir. Sistem girdileri işçilik, arızalı ekipman, malzeme ve yedek parçalar, aletler, bilgiler, politikalar ve prosedürler ve yedek parçalardır. Çıktı ise tesisin planlı çalışmasını sağlamak için güvenilir ve iyi yapılandırılmış ekipmanlardır. Faaliyetler planlama, programlama, yürütme ve kontrolü içerir. Kontrol, bakım sisteminin amaçlarına göre yapılır. Hedeflerin kuruluş hedefleri ile uyumlu olması gerekir ve ekipman bulunabilirliği, maliyetleri ve süreçlerdeki kaliteyi etkiler. Geri bildirim ve kontrol bu sistemde sistem performansını artırmak için kullanılabilecek önemli bir işlevdir. Anahtar süreçleri ve kontrol fonksiyonu olan tipik bir bakım sistemi Şekil 4'te gösterilmektedir. Etkili bir bakım kontrol sistemi ekipman güvenilirliğini arttırır ve kaynakların optimum kullanımına yardımci olur [14].

Bütün tesisler gibi otellerde de bina bileşenleri bozulur, yıpranır veya arızalanır. Binalar var oldukları sürece: çelik kısımları paslanır, camları kırılır, motor yatakları aşınır, borular paslanır ve çatılar sızar. Binalarda ve otellerde bakımın amacı, bu bina bileşenlerini mümkün olduğunca uzun süre çalışır durumda tutmak ve ekipman arızalarının meydana gelmesini azaltmak veya tamamen ortadan kaldırmaktır. Bozulmanın ve 
aşınmanın normal etkilerini minimumda tutmakla bakımın en temel amaçları arasında sayılabilir. Bozulmayı önlemenin en etkili yolu önleyici veya koruyucu bakım programımım uygulanmasıdır.

Otellerde enerji tasarrufu çatıların ısı kaybına neden olan yalıtımların yapılması, pencerelerden 1sı kaçaklarının önlenmesi, pencere ve kapılarda hava sızıntılarının giderilmesi ve otomatik bina kontrol sistemlerinin düzgün çalışması ile sağlanabilir. Otellerde genellikle, sürekli olarak arızalanan klima veya 1sıtma sistemleri, sızan çatılar, sıkça yanlış alarm veren yangın alarm sistemleri ve çalışmayan tuvalet kapıları, küçük ama şikayetlere neden olan bazı sorunlardır. Bütün bunlar planlı bakım ve onarım uygulamaları ile çözülebilir.

Otel yöneticilerinin, temel bakım ve mühendislik yönetimi kavramlarını, mühendislik verilerinin nasıl analiz edileceğini ve en önemlisi bakım personeli ile kuracağı iletişim yöntemlerini ve mühendislik terminolojilerini anlaması oldukça önemlidir. Oteller konaklama hizmeti sunduklarından ve müşterileri sürekli değiştiğinden, sunulan hizmetlerde can güvenliği; ısıtma, havalandırma ve klima, elektrik, su, ulaştırma, dış çevre ve özel tesis ekipmanlarının çalışır durumda olması ve tehlike arz etmemesi oldukça önemlidir. Bir otel, restoran, kulüp, hastane veya diğer konaklama tesislerinde bakım ve mühendislik sistemlerinin yönetilmesi çok da cazip bir konu değildir. Bakım personeli farkedilmeyen, arka planda çalışan kişilerdir ve ancak sorun olduğunda önemleri anlaşılır. Ancak tasarımdan işletmeye kadar düzgün yönetilen sistemler önemli ölçüde uzun vadeli tasarruflar sağlayabilir; veya tam tersine, bu tür sistemlerin yönetilememesi önemli uzun vadeli maliyetlerle sonuçlanabilir. Konaklama ve yemek servisi yöneticileri, sektörlerindeki mühendislik, bakım ve enerji gereksinimlerinin artan önemi nedeniyle yönetim rollerinin değiştiğini farkındalar. Otellerde, bakım/ mühendislik/enerji alanlarında maliyetler, gelirden üç ila beş kat daha hızlı artmış ve bu artış maliyetlerinin en azından bir kısmını dengeleyen fiyat artışlarına yol açmıştır. Bakım politikası ve enerji tüketimi genellikle birbirine bağlıdır; Örneğin, ekipmanın bakımı yapılmazsa, enerji tüketimi artar ve kullanım ömrü azalır. Normal bakımın ertelenmesi çok kısa süreli tasarruf sağlar. Bakımı geciktiren birçok otel anormal derecede yüksek bakım, onarım ve ekipman değiştirme maliyetleri ile karşı karşıya kalmaktadır [18]. Daha önceleri, teknisyen veya tekniker pozisyonundaki kişilerle yürütülen bakım hizmetleri, günümüzde teknolojik gelişmeler, birimin organizasyon yapısı, bütçe kararları, güvenlik, iş yükü tanımlama ve çizelgeleme, kontrol ve raporlama gibi karmaşık süreçler nedeni ile günümüzde bir mühendislik hizmeti olarak yürütülmektedir.

Binaların bakım ihtiyacı çok yüksektir. Bir ulusun refahı, Gayri Safi Yurt İçi Hasılanın (GSYİH) büyüklüğü ile belirlenir. Birçok ülkede binalar, ülkenin brüt sabit sermaye oluşumunun \% 50'sinden fazlasını aşmaktadır. Birçok gelişmiş ülke, bina stoklarını korumak için inşaat sektöründeki toplam yatırımlarının yarısından fazlasını harca- 
makla kalmaz, aynı zamanda GSYİH'larının yaklaşı \% 10'unu inşa edilen tesislerin bakımı için harcarlar [19]. Hem uygulamada hem de teoride bina bakımı, ürün odaklı değil, teknik olarak hizmet odaklıdır. Bakım yönetimi, bina performansının en iyi şekilde işlev görmesi için kaynakların kullanılmasını içerir. Başka bir deyişle, binaların işletme aşamalarında yüksek performansta olduklarından emin olmanızı sağlar. Otellerde de bakım harcamalarının büyük bir kısmı binaların veya bina yardımcı tesislerinin (1sıtma ve soğutma tesisatı, su tesisatı, elektrik tesisat gibi). Bakım yönetimi uygulaması geniş bir bilgi birikimine dayanır (psikoloji, sosyal, finans, yönetim teorisi, bilim ve mühendislikten türetilmiştir). Bu nedenle de otellerde bakım yönetim sisteminin ele alınması ve incelenmesi oldukça önem arz etmektedir [20].

\section{METODOLOJI}

\subsection{Evren ve Örneklem}

Araştırmanın ana kütlesini, Denizli ilinde faaliyet gösteren 3, 4, 5 yıldızlı oteller ve butik otel işletmelerinde çalışan yöneticiler oluşturmaktadır. Denizli İl Kültür ve Turizm Müdürlüğü verilerine göre, 2020 yılı itibariyle Denizli’de Kültür ve Turizm Bakanlığı'ndan turizm işletme belgeli toplam 40 otel bulunmaktadır. Bunların büyük çoğunluğu il merkezinde olmak üzere ilçelerde de tesisler mevcuttur [21]. Çalışma kapsamında 3, 4, 5 yıldızlı ve butik oteller değerlendirmeye alınmıştır bu nedenle il merkezinde, Pamukkale ve Karahayit'de bulunan çalışmaya dahil edilecek tesis sayısı 29'dur. Araştırma konusu nedeniyle, belirlenen 29 otel ile görüşme için yönetim ile randevu almaya çalışılmıştır ancak sadece 13 tanesiyle görüşme sağlanabilmiştir, bunlardan 12 tanesi veri olarak kullanılmıştır, bir tanesi eksik veri nedeniyle uygun bulunmamıştır.

\subsection{Veri Toplama Yöntemleri}

Araştırmada görüşme yöntemi kullanmıştır. Çalışma otellerde bakım yönetimini incelemektedir ve 3, 4 ve 5 yıldızlı ve butik otellerin otel bakım yöneticileri ile sınırlıdır. Öncelikle konuyla ilgili literatürü araştırması yapılarak konunun çerçevesi belirlenmiş ve ankete katılanlara sorulacak sorular belirlenmiştir. Otel yöneticilerinin bakım yönetimi uygulamalarına bakışını belirlemek için orijinal versiyonu Ghazi [22] tarafından hazırlanmış beşli likert tipinde (1: Çok önemsiz, 5: Çok Önemli) 34 ifade bulunmaktadır. Anketin orijinal halinde yer alan ifadeler Türkçe'ye çevrilmiştir. Bu çeviri anadili Türkçe ve iyi düzeyde İngilizce bilen iki öğretim üyesi tarafından görüş alınarak gerekli düzeltmeler yapılmıştır. Görüşmenin devamında bakım uygulamalarının yanlış uygulanmasından sorumlu engelleri tespit amacıyla beşli likert tipinde (1: Çok önemsiz, 5: Çok Önemli) 10 soru yer almaktadır. Görüşmede yer alan diğer sorularla birlikte tüm sonuçlar bulgular bölümünde paylaşılmıştır. Bu araştırma çerçevesi, literatür taramasına dayalı olarak "Konaklama İşletmelerinde Çalışan Yöneticilerin 
Bakım Yönetimi Uygulamalarına Bakışı” olarak adlandırılmıştır. Otel yönetiminin bakım yönetimine stratejik olarak nasıl yaklaştığı operasyonel ve paydaş görüşlerinin bakış açısını nasıl etkilediği görülmeye çalışılmıştır.

\section{BULGULAR VE TARTIŞMA}

Araştırmaya katılmayı kabul eden bu 12 otelden 3'ü 3 yıldızlı, 5'i 4 yıldızlı, 2'si 5 yıldızlı ve 2'si de butik oteldir (Tablo 1). Örnek sayısı küçük olduğu için gizliliğin korunması ilgili oteller için büyük önem taşımaktadır, katılan oteller için olası özdeşleşmeyi kolaylaştırmayacak şekilde yalnızca toplu veriler (hem oteller hem de katılımcılar için) sunulmaktadır. Bu nedenle çalışmada otel veya kişi adına yer verilmemiştir.

Tablo 1. Denizli'de Görüşme Yapılan Otellerin Dağılımı

\begin{tabular}{|l|c|c|}
\hline & $f$ & $\%$ \\
\hline 3 Yıldız & 3 & 25.0 \\
\hline 4 Yıldız & 5 & 41.7 \\
\hline 5 Yıldız & 2 & 16.7 \\
\hline Butik otel & 2 & 16.7 \\
\hline Toplam & 12 & 100.0 \\
\hline
\end{tabular}

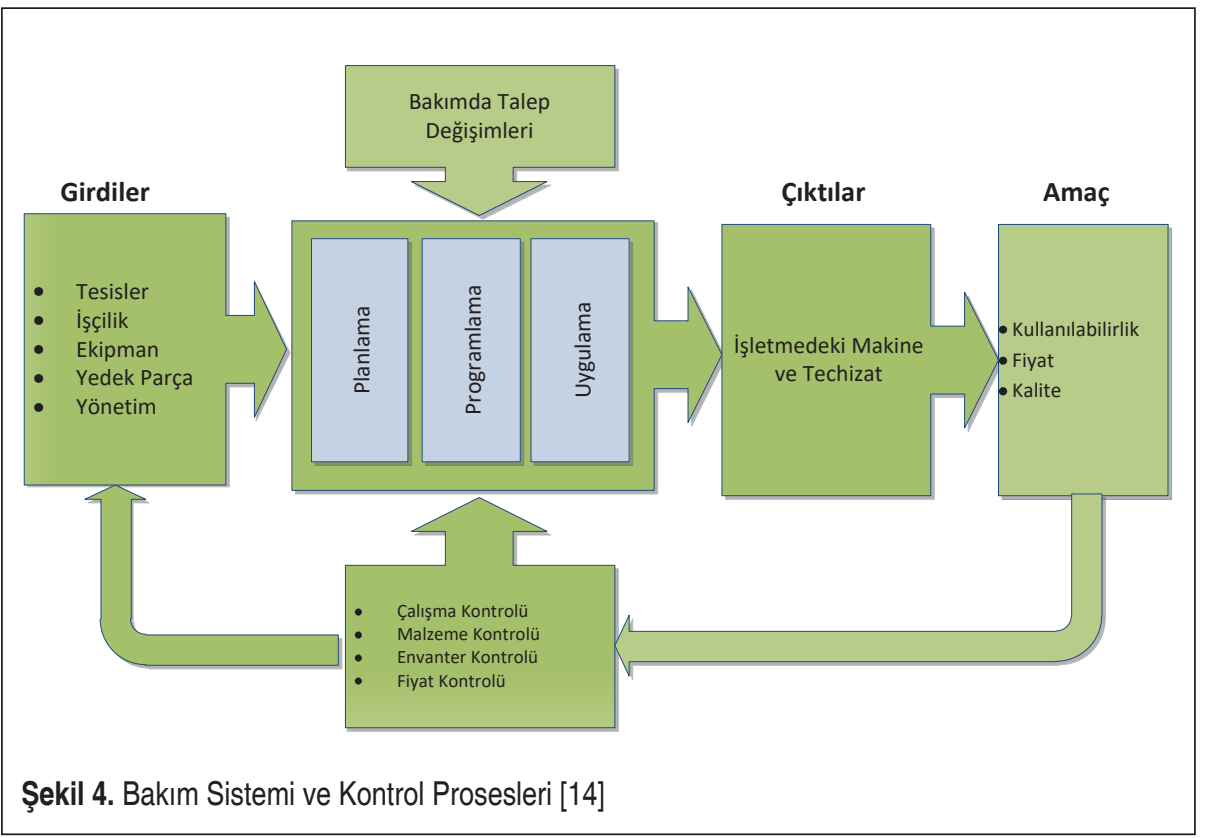


Çalışma ile otel bakım yönetimi uygulamaları ve bakım verimliliğindeki rolü belirlenilmeye çalışılmıştır. Bu kapsamda Tablo 2'de verilen sorular ankete katılan otel yöneticilerine sorulmuş ve 1 ile 5 arasında puan vermeleri istenilmiş̧ir.

Veriler üç bölümde ele alınmıştır;

1. İlk bölümde, Denizli'de bulunan otellerindeki bakım yöneticilerinin bakış açısı ile bakım verimliliği uygulamalarındaki önemini değerlendirilmiştir. Bakım yönetimi, Tablo 2'de de görüleceği üzere 6 ana başlık altında ve toplam 34 ifade ile ele alınmıştır. Katılımcılardan 34 uygulamanın her uygulama için;1-çok önemsiz (en az) ile 5-çok önemli (en yüksek) arasında değişen bir Likert ölçeği kullanarak bakım yönetimindeki önem düzeyi açısından derecelendirmeleri istenilmiştir. Kullanılan değişkenlerin (uygulamaların) önemi, verilen cevapların ortalaması alınarak Tablo 2'de sunulmuştur. Değişkenler (uygulamalar), görüşülen katılımcıların ortalama cevapları yardımıyla da sıralanmıştır.

2. İkinci bölüm, bakım yönetimi uygulamalarının yetersiz uygulanmasından nedeni olan engellerin bakım yöneticilerinin bakış açısından önemi değerlendirmektedir. Uygulamaların kötü uygulanma nedenlerinden 10 nedenden oluşmaktadır. Her bir nedene atanan önem düzeyi yöneticiler tarafından 1-çok önemsiz (en az) ile 5-çok önemli (en yüksek) arasında değişen bir Likert ölçeği kullanarak işaretlemeleri istenilmiştir. Kullanılan değişkenlerin (engeller) önemi, bütün katılımcıların verdiği puanların ortalaması alınarak bulunmuş ve Tablo 2'de verilmiştir. Değişkenler, görüşülen katılımcıların ortalama cevapları yardımıyla da sıralanmıştır.

3. Son bölümde ise, yöneticilerin konfor ve müşteri memnuniyeti açısından, yaptıkları bakım işini nasıl değerlendirdikleri, bakım faaliyetlerini yürütmek için en önemli olduğunu düşündükleri nedenleri, bakım için teknisyen bulma zorlukları, bakım için dış kaynak kullanıp kullanmadıkları ve dış kaynak kullanırken nelere dikkat ettikleri gibi sorular yöneltilmiştir.

\section{Otel Bakım Yönetimi Uygulamaları ve Bakım Verimliliğindeki Rolü}

Tablo 1e'de gösterildiği gibi, 34 ifadenin önem sıralaması ortalamalar alınarak puanları sıralanmıştır; 1.0 çok düşük-en önemsiz ve 5.0 çok yüksek-en önemli şeklindedir. Tabloda bütün kategoriler için ortalamalar alınarak sıralanmıştır. Tablo 2 incelendiğinde görüleceği üzere en düşük ortalama değer 3.58 (14. Bakım personeline eksiksiz teknik dokümantasyon sağlama konusunda üretici/tedarikçi taahhüdü) olurken, en yüksek değer 5 (15. Sayaç okuma gibi günlük bakım (rutin bakım) faaliyetlerini gerçekleştirmek) olarak bulunmuştur.

Her bir ana başlık altındaki sorulara verilen cevapların ortalamaları alınarak ana başlıklar için bir ortalama değer bulunmuştur. Araştırmadaki 6 ana başlık şu şekildedir; Bakım Yönetimi Ekibi, Bakım Yönetim Planı, Bakım Tanımlama ve Değerlendirme, Bakım Eğitimi, Bakım Bilgi paylaşımı ve İletişim, Bakım İzleme Faaliyetleri. Katı- 
Tablo 2. Otel Bakım Yönetimi Uygulamaları ve Bakım Verimliliğindeki Rolü

\begin{tabular}{|c|c|c|c|}
\hline \multicolumn{2}{|r|}{ Otel Bakım Yönetimi Uygulamaları ve Bakım Verimliliğindeki Rolü } & Ort. & Sira \\
\hline \multicolumn{2}{|c|}{ Bakım Yönetimi Ekibi (BYE) } & 4,11 & 5 \\
\hline 1 & $\begin{array}{l}\text { Bakım işinden sorumlu, yeterli ve çok işlevli bir Bakım Yönetim Ekibine sahip } \\
\text { olmak }\end{array}$ & 4,41 & 8 \\
\hline 2 & $\begin{array}{l}\text { Bakımın tüm yönleri için bir Bakım Yönetim Ekip lideri veya benzer bir kişi } \\
\text { olması }\end{array}$ & 4,50 & 7 \\
\hline 3 & Bakım yönetimi için organizasyonel bir idari yapıya sahip olmak & 3,75 & 14 \\
\hline 4 & $\begin{array}{l}\text { Üst düzey yönetim / bakım personeli arasında düzenli BakımYönetim Ekip } \\
\text { toplantıları düzenlemek }\end{array}$ & 4,08 & 11 \\
\hline 5 & Bazı bakım çalışmaları için uzman taşeron firmalar kullanmak & 3,83 & 13 \\
\hline 6 & İyi davranış ve görünüme sahip kalifiye teknisyenler işe almak & 4,08 & 11 \\
\hline 7 & Bakım Yönetim Planı (BYP) & 4,28 & 4 \\
\hline 8 & $\begin{array}{l}\text { Bakım politikasını, standart prosedürleri / stratejiyi içeren yazılı bir Bakım } \\
\text { Yönetim Planı'na sahip olmak }\end{array}$ & 4,50 & 7 \\
\hline 9 & Üst yönetimin (mal sahibi / operatör) BYP uygulamasını onaylanması & 4,58 & 8 \\
\hline 10 & Bakım departmanının Bakım planının geliştirilmesine katılması & 4,41 & 6 \\
\hline 11 & Bakım uzmanlarının tasarım ve inşaat öncesi aşamada yer alması & 3,91 & 12 \\
\hline 12 & $\begin{array}{l}\text { BYP'yi en az yılda bir kez düzenli olarak gözden geçirilmesi ve güncellen- } \\
\text { mesi }\end{array}$ & 4,58 & 6 \\
\hline 13 & Bakım programlarını finanse etmek için yıllık bütçe ayrılması & 4,41 & 8 \\
\hline 14 & $\begin{array}{l}\text { Kilit çalışanları bakım planlama, kaynaklar ve araçlar hakkında bilgilendiril- } \\
\text { mesi }\end{array}$ & 4,25 & 9 \\
\hline 15 & $\begin{array}{l}\text { Bakım personeline eksiksiz teknik dokümantasyon sağlama konusunda } \\
\text { üretici/tedarikçi taahhüdü }\end{array}$ & 3,58 & 16 \\
\hline 16 & Bakım İzleme Faaliyetleri (BiF) & 4,75 & 1 \\
\hline 17 & Sayaç okuma gibi günlük bakım (rutin bakım) faaliyetlerini gerçekleştirmek & 5 & 1 \\
\hline 18 & $\begin{array}{l}\text { Bir hata oluştuktan sonra yapııması gereken bakım işlemlerini gerçekleştir- } \\
\text { mek (Düzeltici / hataya dayalı bakım yaklaşımı) }\end{array}$ & 4,83 & 3 \\
\hline 19 & $\begin{array}{l}\text { Önceden belirlenmiş zaman aralıklarında düzenli / planlanmış faaliyetler } \\
\text { gerçekleştirmek (Önleyici / zamana dayalı bakım yaklaşımı) }\end{array}$ & 4,66 & 5 \\
\hline 20 & $\begin{array}{l}\text { Daha fazla hasar veya olumsuz sonuçlardan kaçınmak için beklenmedik } \\
\text { kusurların acil bakım eylemlerini gerçekleştirmek. (Acil bakım yaklaşımı) }\end{array}$ & 4,50 & 7 \\
\hline 21 & Bakım Bilgi paylaşımı ve İletişim (BBI) & 4,45 & 2 \\
\hline 22 & Bakımı organize etmek için bilgisayarlı bakım bilgi sistemine sahip olmak & 4,16 & 10 \\
\hline 23 & $\begin{array}{l}\text { Bakım prosedürü kontrol listeleri, protokolleri ve çalışma kurallarını bulundur- } \\
\text { mak }\end{array}$ & 4,66 & 5 \\
\hline
\end{tabular}




\begin{tabular}{|c|c|c|c|}
\hline 24 & İyi donanımlı bir bakım komuta merkezine sahip olmak & 4,58 & 6 \\
\hline 25 & Misafirler ve çalışanlar için ücretsiz bir bakım hattına sahip olmak. & 4,41 & 8 \\
\hline 26 & Arıza gören herhangi bir işçi, basılı veya elektronik bir iş emri başlatabilmesi & 4,08 & 11 \\
\hline 27 & Çalışma sıklığı ve tüm detayları içeren bakım çalışmaları takvimi bulunması & 4,58 & 6 \\
\hline 28 & Bina, hizmet, tesis, anlaşma vb. Kayıtların bakımı. & 4,66 & 5 \\
\hline 29 & Bakım Tanımlama ve Değerlendirme & 4,28 & 4 \\
\hline 30 & $\begin{array}{l}\text { Mevcut ve potansiyel bakım sorunlarını ve çalışan tesis yönetimi etkilerini } \\
\text { tanımlanması ve sınıflandırıması }\end{array}$ & 4,66 & 5 \\
\hline 31 & $\begin{array}{l}\text { Hataların veya sorunların meydana geldiğini bildirmek için etkili ve hızlı yön- } \\
\text { temler belirlenmesi }\end{array}$ & 4,41 & 8 \\
\hline 32 & $\begin{array}{l}\text { İhtiyaç duyulan ekipman ve malzemeyi, özelliklerini ve varsayılan yaşını } \\
\text { (sanallaştırma), bakım geçmişini, intiyaç duyulan vasıfı ışçiliği, maliyetleri, } \\
\text { uygulama araçlarını ve finansman kaynaklarının tanımlanması }\end{array}$ & 4,08 & 11 \\
\hline 33 & $\begin{array}{l}\text { Doluluk sonrası bakım performansının, takip eylemlerinin değerlendirilmesi } \\
\text { ve ölçülmesi. }\end{array}$ & 4,41 & 8 \\
\hline 34 & $\begin{array}{l}\text { Müşterileri ve çalışanları, hizmetlerin bakımıyla ilgili görüşlerini bildirmeye } \\
\text { teşvik etmek. }\end{array}$ & 3,83 & 13 \\
\hline 35 & Bakım Eğitimi (BE) & 4,29 & 3 \\
\hline 36 & $\begin{array}{l}\text { Personel becerilerini geliştirmek ve yeni teknolojiyi öğrenmek için en az } \\
\text { yılda bir kez düzenli olarak bakım eğitimi (tatbikatlar, seminerler, atölyeler) } \\
\text { düzenlemek }\end{array}$ & 4,75 & 4 \\
\hline 37 & Yeni personelin bakım konusunda eğitilmesi & 4,83 & 2 \\
\hline 38 & Üreticiler veya tedarikçilerin eğitim oturumları sağlama taahhüdü vermesi & 3,91 & 12 \\
\hline 39 & $\begin{array}{l}\text { Temizlik personelinin, bakımı kolaylaştırmak için ya da bakım ekibinin olma- } \\
\text { dığı zamanlarda (özellikle gece), kilit, ampül ya da bataryaları değiştirmek } \\
\text { gibi görevler konusunda eğitilmesi. }\end{array}$ & 3,66 & 15 \\
\hline
\end{tabular}

lımcıların verdikleri cevaplar incelendiğinde en önemli konu 4.75 ortalama ile Bakım İzleme Faaliyetleri olarak görülmektedir. En az önemli konu ise 4.11 ortalama ile Bakım Yönetimi Ekibi olarak görülmektedir. Bu sonuç, otel yöneticilerinin bakım yönetim ekibinin rolünü önemsemediklerini ancak diğer yandan Bakım İzleme Faaliyetlerini ise oldukça önemsediklerini göstermektedir. "Sayaç okuma gibi günlük bakım (rutin bakım) faaliyetlerini gerçekleştirmek" faaliyeti bütün ankete katılanlardan 5 puan almıştır.

Tablo 3'te ise bakım uygulamalarının kötü uygulanmasından sorumlu engeller belirlenilmeye çalışılmıştır. Genel ortalama 3.81 olarak bulunmuştur. En yüksek 4.41 olurken en düşük 2.41 (S8: Otel sahibi / operatör isteksizliği) değeri bulunmuştur. 
Tablo 3. Bakım Uygulamalarının Kötü Uygulanmasından Sorumlu Engeller

\begin{tabular}{|l|r|r|}
\hline Bakım uygulamalarının yanlış uygulanmasından sorumlu engeller. & \multicolumn{1}{|c|}{ Ort. } & \multicolumn{1}{c|}{ Sıra } \\
\hline S1: Kullanıcıların tutumu ve tesislerin kötüye kullanılması & 4,25 & 3 \\
\hline S2: Bakım çalışmaları için yetersiz fon & 3,58 & 6 \\
\hline S3: İşletme yaşı ve çevre nedeniyle doğal bozuıma & 3,75 & 5 \\
\hline S4: Bakım maliyetinin operatörler tarafından şişirilmesi & 2,91 & 7 \\
\hline $\begin{array}{l}\text { S5: Yabancılar tarafından tasarlanan ve yapılan binalarda çalışmayı sürdürecek } \\
\text { kalifiye insan gücü eksikliği }\end{array}$ & 4,00 & 4 \\
\hline $\begin{array}{l}\text { S6: Verimsiz envanter sistemi veya kullanılamayan fon nedeniyle sık sık malzeme } \\
\text { ve yedek parça sıkıntısı }\end{array}$ & 4,41 & 1 \\
\hline S7: Bakım departmanında vasıflı personel eksikliği & 4,33 & 2 \\
\hline S8: Otel sahibi / operatör isteksizliği & 2,41 & 8 \\
\hline $\begin{array}{l}\text { S9: Eğitimin yetersiz olması ve öneminin belirlenmesi, yeniden eğitme ve eğitime } \\
\text { devam etme }\end{array}$ & 4,25 & 3 \\
\hline S10: Ülkede fark edilir bakım kültürü eksikliği & 4,25 & 3 \\
\hline \multicolumn{1}{|c|}{ Genel Ortalama } & 3,81 & - \\
\hline
\end{tabular}

Tablo incelendiğinde görüleceği üzere en büyük problem olarak "verimsiz envanter sistemi veya kullanılamayan fon nedeniyle sık sık malzeme ve yedek parça sıkıntısı" görülmektedir. Bu ifadeleri "Bakım departmanında vasıflı personel eksikliği” izlemektedir. En az problem olarak ise Otel sahibi / operatör isteksizliği görülmektedir. Otel yöneticileri problemlerin kendileri dışından kaynaklandığını düşünmektedirler.

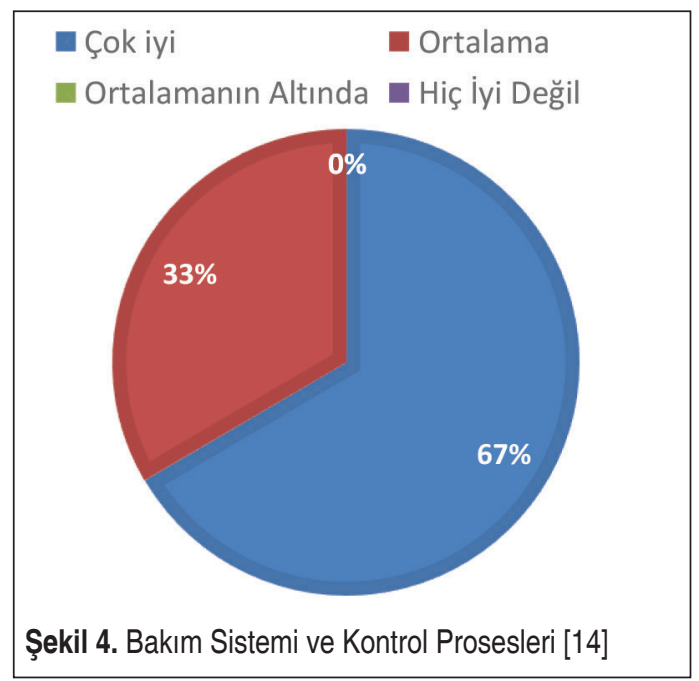




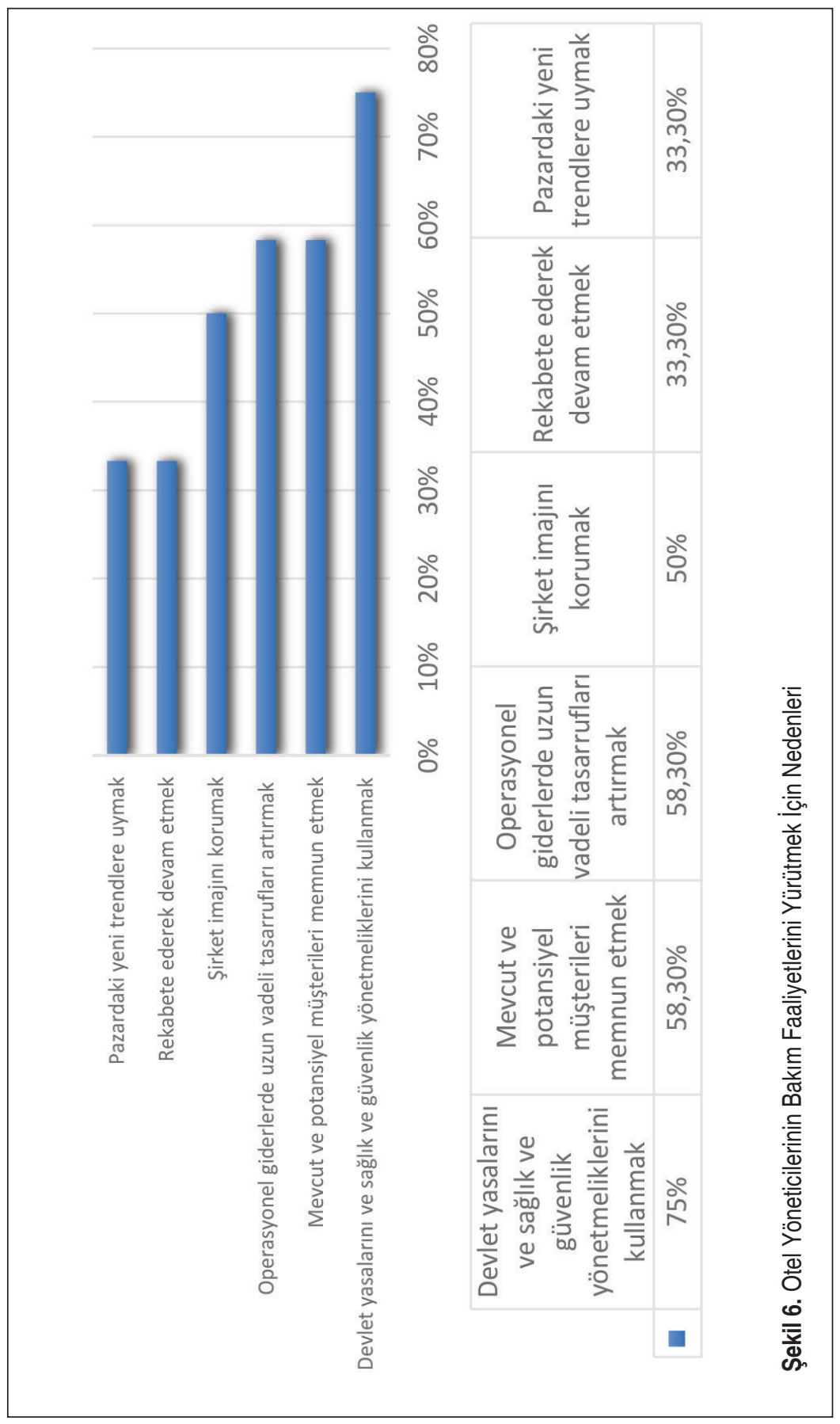


Yapılan görüşmede otel yöneticilerine konfor ve müşteri memnuniyeti açısından, yaptıkları bakım işini nasıl değerlendirdikleri görülmeye çalışılmıştır. Elde edilen sonuçlara göre \%33.3 yapılan bakımı ortalama bulurken, \%66.7'si çok iyi olarak değerlendirmiştir (Şekil 5). Katılımcılardan hiçbirisi ortalamanın altında veya iyi değil seçeneğini işaretlememişlerdir. Bu da otel yöneticilerinin yürütülen bakım faaliyetlerinden genel olarak memnun olduklarını göstermektedir.

Otel yöneticilerine bakım faaliyetlerini yürütmek için en önemli olduğunu düşündükleri nedenlerin belirlenmesi amacı; rekabete ederek devam etmek, şirket imajını korumak, pazardaki yeni trendlere uymak, devlet yasalarını ve sağlık ve güvenlik yönetmeliklerini kullanmak, mevcut ve potansiyel müşterileri memnun etmek, operasyonel giderlerde uzun vadeli tasarrufları artırmak soruları yöneltilmiş ve bu sorular içerisinden istedikleri seçenekleri seçmeleri istenmiştir. Katılımcıların verdikleri cevaplar Şekil 6'da verilmiştir. Şekilde görüldüğü gibi yasalar ve yönetmeliklerin zorlay1cı etkileri \%75 ile ilk sırada yer almaktadır. Bunu mevcut ve potansiyel müşterilerin memnuniyetini sağlamak ve operasyonel giderlerde uzun vadeli tasarrufları artırmak (\%58.3) izlemektedir. En önemsemedeikleri nedenler ise \%33.3 ile rekabete ederek devam etmek ve pazardaki yeni trendlere uymak olarak görülmektedir.

Otel yöneticilerine "Otel endüstrisinde bakım hizmeti için teknisyen bulmak kolay mıdır?” sorusunu yönelttiğimizde \%16,7'si hayır yanıtını verirken \%83,3'ü evet yanıtını verdi (Şekil 7). Katılımcıların büyük bir çoğunluğunun evet cevabı vermesi, otellerin kolay bir şekilde teknisyen bulabildiklerini göstermektedir.

Otel işletmecisi olarak deneyiminizde, aşağıdaki operasyonel fonksiyonlardan hangisi genellikle otellerde dış kaynak kullanımı gerektirir? Sorusuna verilen yanıtlar Şekil

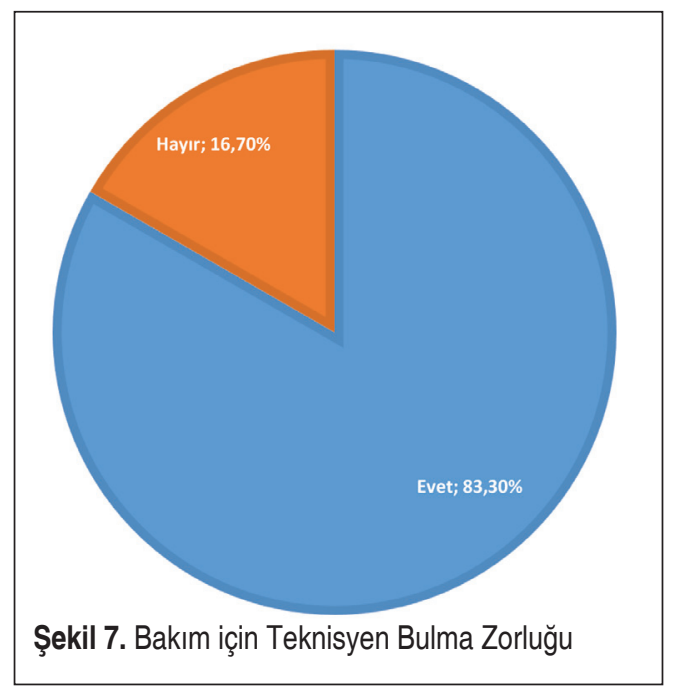




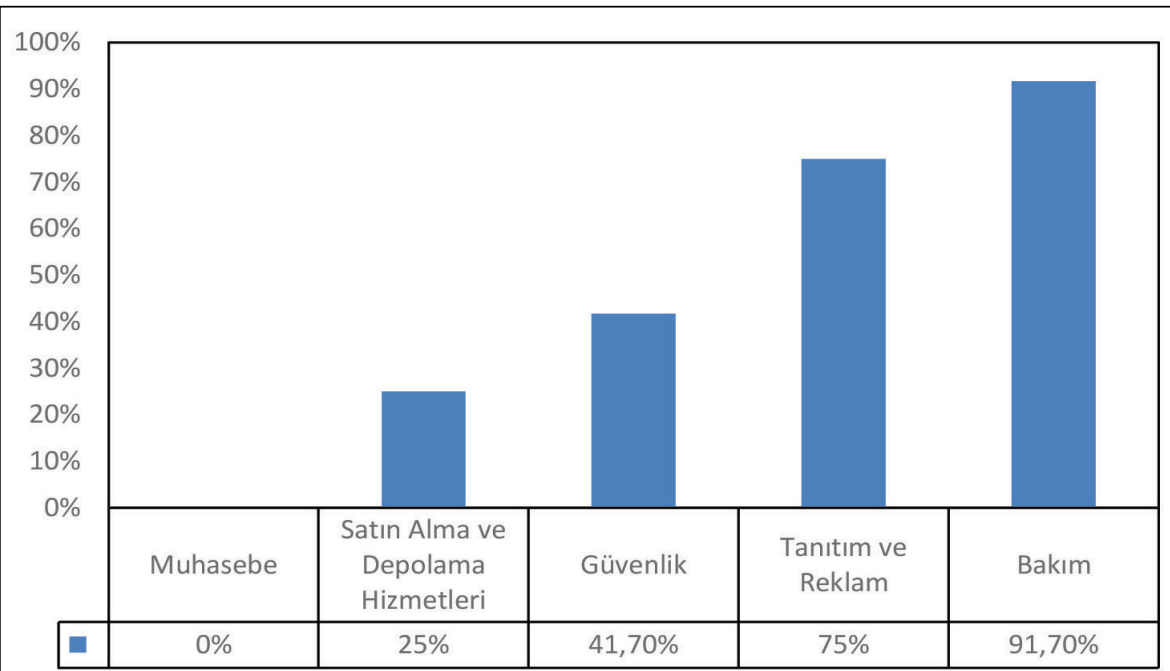

Şekil 8. Dış Kaynak Kullanımı

8'de verilmiştir. Buna veri doğrultusunda görüşme yapılan 12 otelden 11 tanesinin (\%91.7) bakım hizmetleri için dış kaynak kullandığı, bunun dışında tanıtım ve reklam için (\%75) ile güvenlik ve satın alma (\%41.7) için dış kaynak kullanırken muhasebe için dış kaynak kullanılmadığı görülmüştür.

Bir diğer soru ile otel yöneticilerine dış kaynak seçiminde nelere dikkat ettikleri sorulmuştur. Bu soruya verdikleri yanıtlar Şekil 9'da gösterilmiştir. 12 otel içersinde

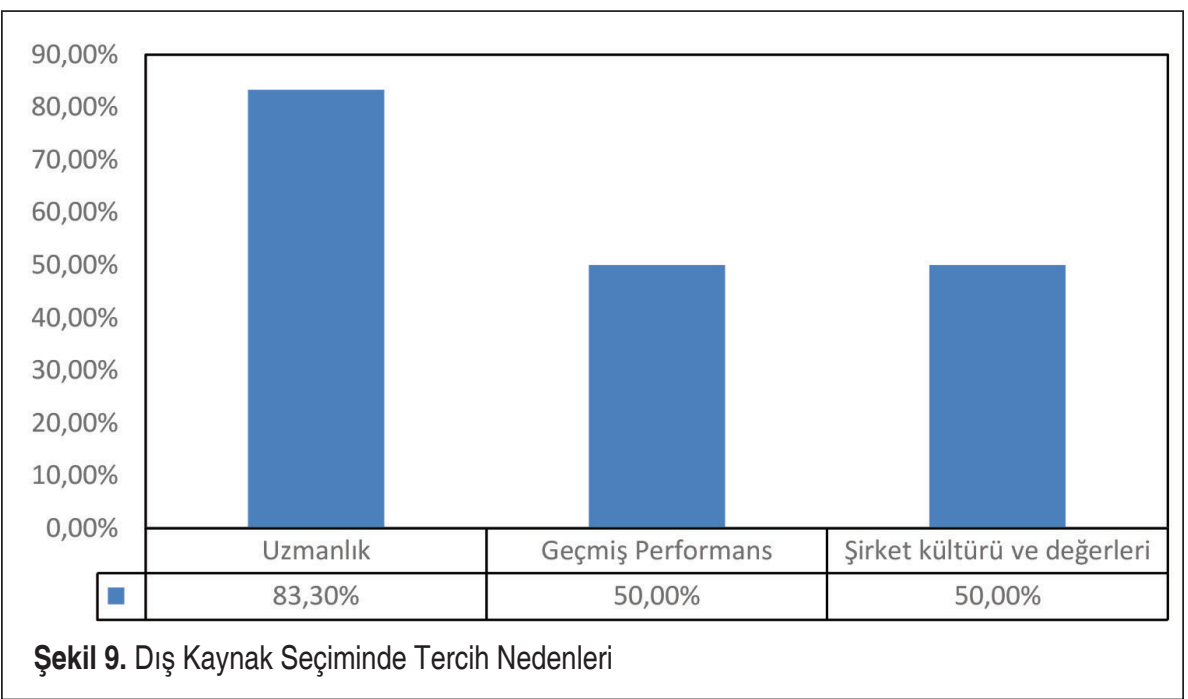



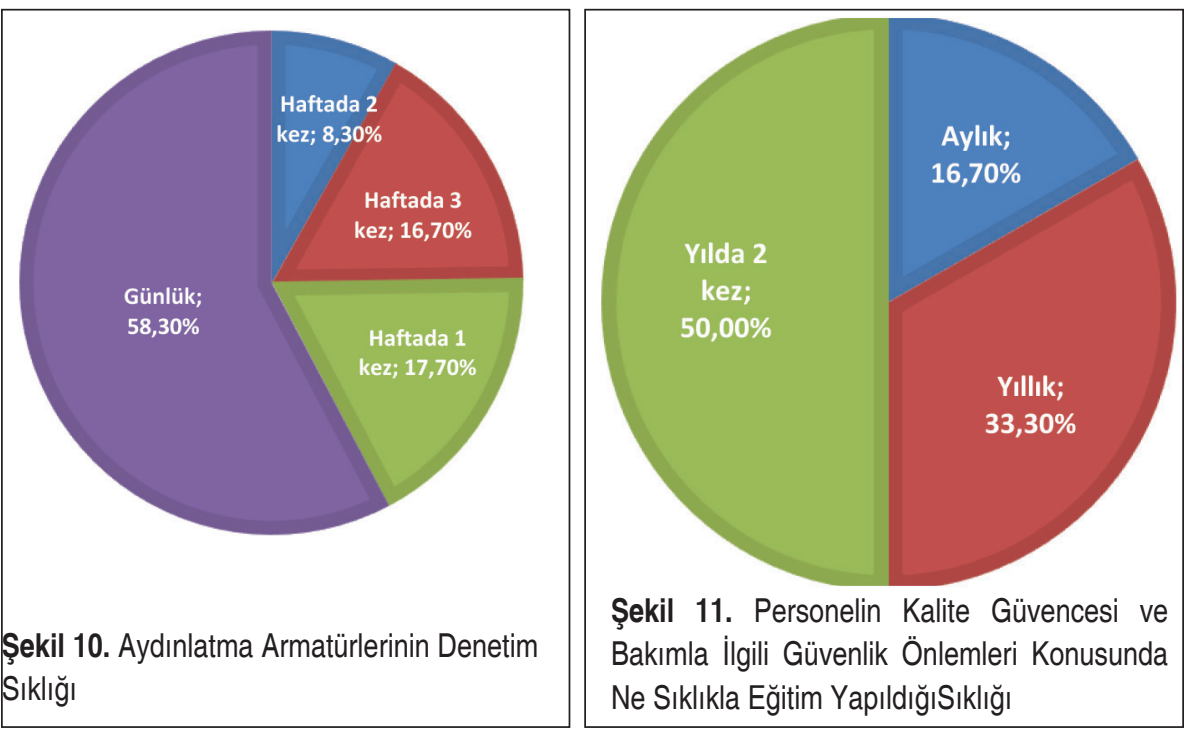

10 tanesi (\%83) uzmanlığa dikkat ederken 6 tanesi (\%50) geçmiş performansa, 6 tanesi $(\% 50)$ ise şirket kültürünün ve değerlerin dış kaynak seçiminde etkili olduğunu belirtmiştir. Ankete katılan yöneticilerin büyük çoğunluğunun uzmanlığı önemsediği görülmektedir. Diğer yandan önceki çalışmaların ve iyi veya kötü deneyimlerin de önemli olduğu anlaşılmaktadır.

Bir diğer soru ile bakımın hangi sıklıkta yapıldığ kapsamda katılımcılara "Otel odalarındaki aydınlatma armatürlerinin ne sıklıkla denetlenmesi gerektiğini düşünüyorsunuz?” sorusu yöneltilmiştir. Bu soruya verilen cevaplar Şekil 10'da veilmiştir. Şekil 10'dan da görüldüğü gibi katılımcıların çok büyük bir çoğunluğu (\%58.3) günlük olarak kontrol yapılmasını sağlarken haftada 3 kez sağlayanlar \%16.7 ve haftada $1 \mathrm{kez}$ kontrol yapılmasını sağlayanlar ise \%17.7 olarak gerçekleşmektedir.

Otellerde bakım konusunda eğitim sıklığının belirlenmesi amacı ile katılımcılara personelin kalite güvencesi ve bakımla ilgili güvenlik önlemleri konusunda ne sıklıkla eğitim yapıldığg sorulmuştur. \%50'si yılda iki kez eğitim verildiğini, \%33.3'y1llık eğitimler planladıklarını, \%16,7'sı ise aylık eğitimler verdiklerini belirtmiştir. Şekilden de görüldüğü gibi yöneticilerin yarısı yılda iki kez eğitim verildiğini belirtmişlerdir, Şekil 11.

Bakım konusunda verilen bu eğitimler neticesinde eğitim alanlara sertifika verilip verilmediği sorulmuş ve yanıtlar Şekil 12'de paylaşılmıştır. Şekil 12'de görüldüğü gibi katılımcıların çok büyük bir çoğunluğu (\%84) eğitim konusunda sertifika verilmesini önemsemektedirler. 


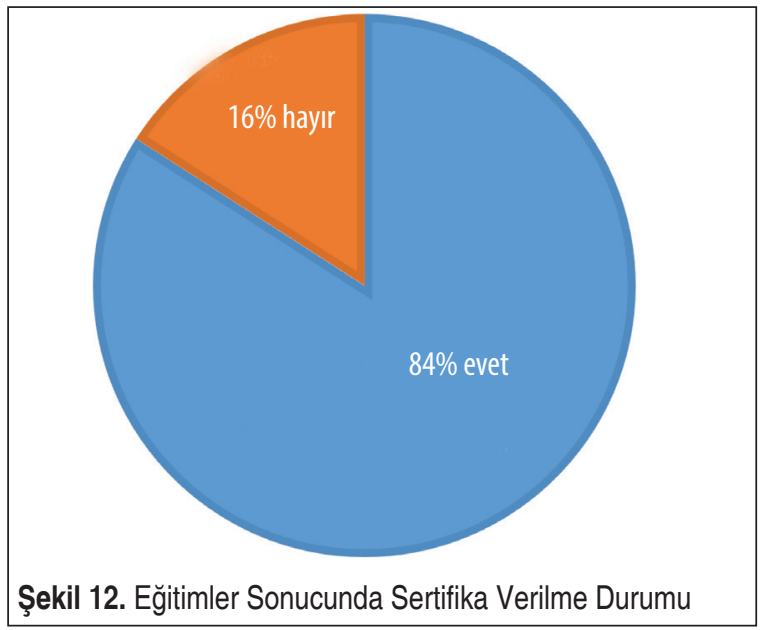

\section{SONUÇ}

Bakım yönetimi, enerji verimliliğini artırmak ve toplam maliyetleri optimum tutmak için oldukça önemli bir rol oynar. Otellerde kullanılan cihazların, işletim ve bakım maliyetleri ile enerji tüketiminin azaltılması için ekipmanların bakımları uygun bir şekilde yapılmalı ve kontrol edilmelidir. Otel endüstrisinde yaygın olarak wbenimsenen stratejiler arasında, yöneticilerin zorlu iş ortamlarında işletme maliyetlerini azaltmak için dış kaynak kullanımı bulunmaktadır. Bakım hizmetlerinin de bir kısmının dış kaynaklardan sağlandığı bilinmektedir. Böyle bir stratejinin amacı verimliliği ve gelirlerini artırmaktır. Otellerin kendi alanlarına odaklaması ve sürekli değişen iş ortamına uyum sağlama yeteneğini güçlendirmesi bu yöntemle sağlanabilir.

Yapılan çalışmada bakım hizmetlerin büyük bir kısmının dış kaynaklardan sağlandığı görülmüştür. Otel işletmecileri için bakımla ilgili önemli olan konu, bakım ve işletme maliyetinin artması ve enerji verimliliğinin sağlanmasıdır. İşletmelerin bakım personelin sertifikalandırlması konusuna önem verdikleri de bulgular arasında yer almıştır. Yapılan çalışmada, katılımcılar, bakım faaliyetlerinin yürütülmesi konusunda en büyük etkinin yasa ve yönetmeliklerdeki zorlamalar olduğunu ve aynı zamanda müşreti memnuniyetinin sağlanması ve giderlerin azaltılması konusunun da belirleyici olduğunu belirtmişlerdir. Bu sorumlulukları yerine getirirken hem çalışanların hem de müşterilerin ilgi ve görüşlerinin dikkate alındığı yapılan çalışmalar ile ortaya konulmuştur. Bakım uygulamalarının önündeki en büyük sorun olarak verimsizlik ve sık sık malzeme ve yedek parça sıkıntısı olduğu belirtilmiştir. Katılımcıların tümü sayaç okunması gibi günlük günlük rutin bakım faaliyetlerini çok önemsediklerini ortaya koymuşlardır. Bakım personelinin eğitimesi, arıza sonrası düzeltici faaliyetlerin yapılarak onarımın gerçekleştirilmesi de katılımcılarca önemli konular arasında görülmektedir. 
Yapılan çalışma sonucunda, özelikle otellerde bakım konusunda uzmanlaşmış, eğitimli ve sertifikalı bakım personeli konusunda bir ihtiyaç olduğu gözlemlenmiştir. Otellerde rutin bakım faaliyetlerinin yürütüldüğü ve yöneticilerin bakım konusunda farkındaliklarının olduğu da ortaya çıkarılmıştır.

\section{KAYNAKÇA}

1. Chan, K. T., Lee, R. H. K., \& Burnett, J. 2001. "Maintenance Performance: A Case Study of Hospitality Engineering Systems," Facilities, vol. 19, no. 13/14, p.494-504. doi:10.1108/02632770110409477.

2. Lai, J. H. 2013. "An Analysis of Maintenance Demand, Manpower, and Performance of Hotel Engineering Facilities," Journal of Hospitality \& Tourism Research, vol. 37, no. 3, p.426-444. doi:10.1177/1096348012436380.

3. Campbell, J. D. 1995. Strategies in Excellence in Maintenance Management, Productivity Press, Portland.

4. Campbell, J. D., Jardine, A. K. 2001. Maintenance Excellence: Optimizing Equipment Lifecycle Decisions, Campbell JD, Jardine, A.K., Eds., CRC Press, New York.

5. Xiang, Z., Schwartz, Z., Gerdes, J. H., Uysal, M. 2015. "What Can Big Data and Text Analytics Tell us About Hotel Uuest Experience and Satisfaction?,” International Journal of Hospitality Management, vol. 44, no. 1, p.120-130. doi:10.1016/j.ijhm.2014.10.013.

6. Mattila, A. S., \& O'Neill, J. W. 2003. "Relationships Between Hotel Room Pricing, Occupancy, and Guest Satisfaction: A Longitudinal Case of a Midscale Hotel in the United States," Journal of Hospitality \& Tourism Research, vol. 27, no. 3, p.328-341. doi:10.1177/1096348003252361.

7. Li, H., Ye, Q., Law, R. 2013. "Determinants of Customer Satisfaction in the Hotel Industry: An Application of Online Review Analysis," Asia Pacific Journal of Tourism Research, vol. 18, no. 7, p.784-802. doi:10.1080/10941665.2012.708351.

8. Arenas, E. F., Colina, N. V. 2010. "The Planned Preventive Maintenance in Hotel Facilities: An Undeferrable Priority," Retos Turísticos, vol. 9, no. 1, p.45-47.

9. Longart, P. 2020. "Understanding Hotel Maintenance Management," Journal of Quality Assurance in Hospitality \& Tourism, vol. 21, no. 3, p.267-296. doi: 10.1080/1528008X.2019.1658148

10. Garg, A., Deshmukh, S. G. 2006. "Maintenance Management: Literature Review and Directions," Journal of Quality in Maintenance Engineering, vol. 12, no. 3, p.205-238. doi:10.1108/13552510610685075

11. Rutherford, D. G., O'Fallon, M. J. 2007. Hotel Management and Operations, John Wiley \& Sons., Organizational Design, Eddystone C. Nebel III.

12. Mutlu Öztürk, H., Öztürk, H. K. 2019. "Maintenance and Maintenance Management Systems in Accommodation," Journal of Achievements in Materials and Manufacturing Engineering, vol. 96, no. 2, p.83-93. doi: 10.5604/01.3001.0013.7938. 
13. Seeley, I. H. 1987. Building Maintenance, Macmillan International Higher Education, New York.

14. Ben-Daya, M., Duffuaa, S. O., Raouf, A., Knezevic, J., Ait-Kadi, D. 2009. Handbook of Maintenance Management and Engineering, Vol. 7, Springer, London.

15. Narayan, V. 2004. Effective Maintenance Management: Risk and Reliability Strategies for Optimizing Performance, Industrial Press Inc., New York.

16. Cruzan, R. 2009. Manager's Guide to Preventive Building Maintenance, The Fairmont Press Inc., Lilburn.

17. Öztürk, H. K., Öztürk, H. M., Dombaycı, Ö. A. 2018. "Turizm sektöründe enerji tüketimi ve enerji tasarruf olanakları," Güncel Turizm Araştırmaları Dergisi, cilt. 2, sayı 1, s.17-28.

18. Bennett, D. 2009. Maintenance Management, First Edition, Global Media, Delhi.

19. Olanrewaju, A. L., Abdul-Aziz, A. R. 2014. Building Maintenance Processes and Practices: The Case of a Fast Developing Country, Springer, Singapore.

20. Son, L. H. 1993. Building Maintenance Technology, Macmillan International Higher Education, London.

21. KYI. 2020. "Konaklama ve yeme -İçme, Denizli İl Kültür ve Turizm Müdürlügü̈”, https://denizli.ktb.gov.tr/TR-211864/konaklama---yeme---icme.html, son erişim tarihi: 20.05.2020.

22. Ghazi, K. M. 2016. "Maintenance Management Practices in 5-star Hotels," International Journal of Heritage, Tourism, and Hospitality, vol. 10, no. 1/2, p.161-191. 